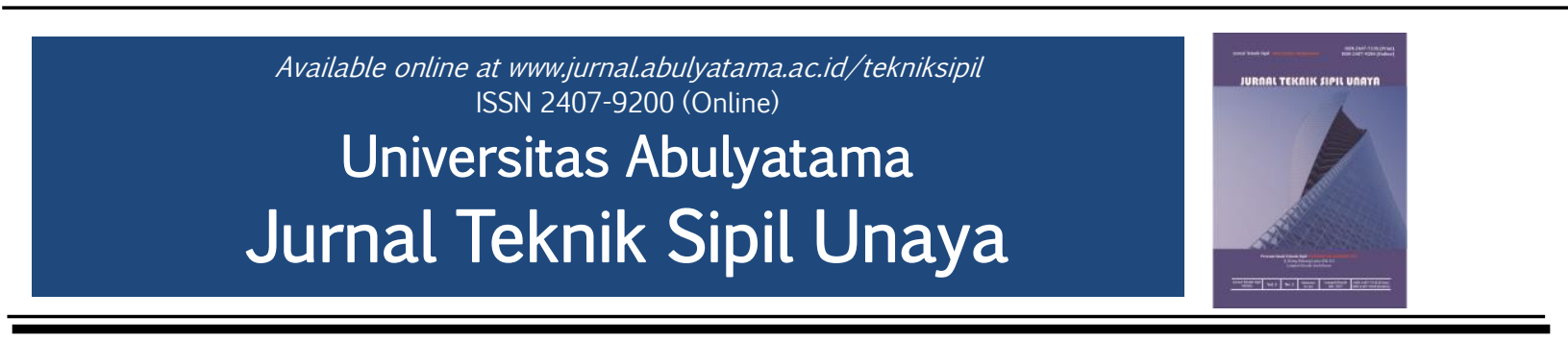

\title{
Analisis Tarif Angkutan Umum Berdasarkan Biaya Operasi Kendaraan
}

\author{
Muhammad Zardi $^{1}$, Meliyana ${ }^{1}$, Defi Mahdiahinda ${ }^{1}$ \\ ${ }^{1}$ Program Studi Teknik Sipil, Fakultas Teknik, Universitas Abulyatama, Jl. Blang Bintang \\ Lama Km 8,5 Lampoh Keude Aceh Besar, 23372, Indonesia \\ *Email korespondensi : muhammadzardi_sipil@abulyatama.ac.id ${ }^{1}$
}

Diterima 13 Mei 2018; Disetujui 5 Juli 2018; Dipublikasi 31 Juli 2018

\begin{abstract}
The aim of this study is to analyze the Vehicle Operational Cost (VOC) and tariff based on the calculation of VOC and compare with the prevailing tariff in Blang Pidie-Banda Aceh route. Primary data was carried out by surveys, among others, physically survey of the vehicles, number of vehicles and passengers, and investigation survey. Secondary data was obtained from the relevant government institutions. The results of the analysis showed that the average passenger load factor of the inter-city transportation route of Blang Pidie-Banda is $56.25 \%$. The average tariff set by the government is Rp. 106,500/passenger, the average tariff calculated by VOC for Blang Pidie-Banda Aceh route is Rp. 114,014/passenger, while the average rate applied in the field is Rp. 125,000/ passenger. The calculation of Cost of Production (COP) is Rp. 103,649/passenger-km. While the ability to pay (ATP) of the public transport services users is Rp. 208,333. Tariffs based on Vehicle Operating Cost (VOC) are smaller than the prevailing rates in the field and the rates applicable in the field are also higher than the rates set by the local municipality.
\end{abstract}

Keywords : tariff analysis, $V O C, A T P$

Abstrak: Penelitian ini bertujuan untuk mengetahui besarnya Biaya Operasional Kendaraan (BOK) dan tarif berdasarkan hasil hitungan BOK serta membandingkannya dengan tarif yang berlaku di lapangan pada trayek Blang Pidie - Banda Aceh. Data primer dilakukan dengan survei ke lapangan antara lain survei terhadap kendaraan secara fisik, jumlah angkutan dan jumlah penumpang dan survei investigasi. Sedangkan data sekunder diperoleh dari instansi-instansi pemerintah terkait. Dari hasil analisa diketahui Faktor muatan penumpang rata-rata angkutan antar kota trayek Blang Pidie - Banda adalah sebesar $56,25 \%$. Tarif rata-rata yang ditetapkan pemerintah adalah Rp.106.500/Pnp, tarif rata-rata hasil perhitungan BOK trayek Blang Pidie - Banda Aceh adalah Rp. 114.014,-/pnp, sedangkan tarif rata-rata yang berlaku di lapangan adalah Rp. 125.000,-/pnp. Hasil perhitungan Biaya Pokok Produksi (BPP) sebesar Rp. 103.649,- /pnp-km. Sementara kemampuan membayar pengguna jasa angkutan umum ATP (Ability To Pay) sebesar Rp. 208.333,-. Tarif berdasarkan Biaya Operasional Kendaraan (BOK) lebih kecil bila dibandingkan dengan tarif yang berlaku di lapangan dan tarif yang berlaku di lapangan juga lebih tinggi dari tarif yang ditetapkan Pemerintah kota setempat.

Kata kunci: analisis tarif, BOK, ATP 
Transportasi merupakan salah satu aspek penunjang kemajuan suatu daerah terutama dalam kegiatan perekonomiannya. Hal ini tidak lepas dari pengaruh pertambahan jumlah penduduk. Semakin bertambahnya jumlah penduduk maka semakin meningkat kebutuhan sarana dan prasarana transportasi. Salah satu sarana transportasi yang terus meningkat adalah angkutan umum. Angkutan umum merupakan angkutan yang disediakan untuk keperluan umum yang dilakukan dengan sistem sewa dan bayar dapat berupa mobil penumpang, bus kecil, bus sedang dan bus besar. Umumnya masyarakat menghendaki pelayanan angkutan umum yang aman, cepat, murah dan nyaman. Tamin (2000), mengatakan bahwa tujuan dasar penyediaan angkutan umum adalah menyediakan pelayanan angkutan yang baik, handal, nyaman, aman, cepat dan murah untuk umum.

Pemerintah daerah menetapkan besarnya tarif angkutan dengan menetapkan batas atas (tarif maksimum) dan batas bawah (tarif minimum) yang disesuaikan dengan besarnya biaya operasi kendaraan, sehingga diharapkan agar besarnya tarif yang akan dibebankan kepada penumpang tidak memberatkan atau sesuai dengan ketentuan yang berlaku serta memberi keuntungan wajar kepada pihak pengusaha angkutan.

Berdasarkan Tamin (1999) penentuan tarif juga akan sangat berpengaruh pada besarnya Ability To Pay (ATP) dan dari masyarakat pengguna jasanya. ATP adalah kemampuan seseorang untuk membayar jasa angkutan yang diterimanya berdasarkan penghasilan yang dianggap ideal. Atas dasar inilah penulis melakukan penelitian terhadap penentuan tarif angkutan umum antar kota yang didasarkan pada biaya operasional kendaraan dan membandingkannya dengan tarif yang telah berlaku selama ini serta mengevaluasi kemampuan membayar (ATP) dari para penumpang sebagai pengguna jasa.

Kota Blang Pidie merupakan salah satu kota di Propinsi Aceh yang memiliki permasalahan transportasi yang cukup menarik. Transportasi dari Blang Pidie ke Banda Aceh pada umumnya melalui geometrik dataran dan pegunungan bukit barisan. Kondisi geografis perbukitan dengan jalan yang berkelok-kelok merupakan penyebab kesulitan transportasi. Saat ini transportasi dari Blang Pidie ke Banda Aceh memiliki 10 perusahaan angkutan yang melayani perjalanan masyarakat. Tarif yang berlaku saat ini dari Blang Pidie ke Banda Aceh Rp. 125.000 - Rp. 150.000 sementara tarif umum dari Organisasi Angkutan Darat (Organda) Rp. 106.500 - Rp. 124.500. Penetapan tarif oleh Pemerintah Daerah terus mengalami perubahan sesuai dengan perkembangan ekonomi, antara lain karena kenaikan harga Bahan Bakar Minyak (BBM), inflasi dan pengaruh harga pasar. Kenaikan harga BBM misalnya, akan mengakibatkan bertambahnya biaya operasional kendaraan yang pada akhirnya akan dibebankan kepada pengguna jasa angkutan tersebut. Oleh karena itu, diperlukan adanya penelitian untuk 
mengetahui besarnya Biaya Operasional Kendaraan (BOK) dan tarif berdasarkan hasil hitungan BOK serta membandingkannya dengan tarif yang berlaku di lapangan.

\section{KAJIAN PUSTAKA}

\section{Transportasi Umum}

Transportasi merupakan proses pergerakan atau perpindahan manusia dan barang dari satu tempat ke tempat lain untuk tujuan tertentu.

Konsep transportasi didasarkan pada adanya perjalanan (trip) antara asal (origin) dan tujuan (destination). Menurut Pahlevi (2006), ada lima unsur pokok transportasi, yaitu:

1) Manusia, yang membutuhkan transportasi.

2) Barang, yang dibutuhkan manusia.

3) Kendaraan, sebagai sarana transportasi.

4) Jalan, sebagai prasarana transportasi.

5) Organisasi, sebagai pengelola angkutan.

Pada dasarnya, ke lima unsur di atas saling terkait untuk terlaksananya transportasi yang menjamin penumpang atau barang yang diangkutnya akan sampai ke tempat tujuan dalam keadaan baik seperti pada saat awal diangkut. Dalam hal ini perlu diketahui terlebih dulu ciri penumpang dan barang, kondisi sarana dan konstruksi prasarana, serta pelaksanaan transportasi.

\section{Angkutan Umum}

Menurut Warpani (2002), angkutan adalah kegiatan perpindahan orang dan barang dari satu tempat (asal) ke tempat lain (tujuan) dengan menggunakan kendaraan. Kendaraan adalah $\underline{\text { suatu alat yang dapat bergerak dijalan, terdiri }}$ dari kendaraan bermotor atau kendaraan tidak bermotor. Angkutan Umum Antar Kota adalah semua jenis angkutan umum yang melayani perjalanan (trips) penumpang dari tempat asal (origin) ke tujuan (destination) dalam perkotaan.

Angkutan umum bersifat angkutan massal sehingga biaya angkut dapat dibebankan kepada lebih banyak orang atau penumpang.

Untuk melakukan pergerakan maka manusia memerlukan angkutan umum. Adapun alasan-alasan yang menyebabkan orang melakukan pergerakan/ perjalanan adalah sebagai berikut:

1. Berdasarkan tujuan

2. Berdasarkan waktu

3. Berdasarkan jenis orang

Hal ini merupakan salah satu jenis pengelompokkan yang penting karena perilaku pergerakan individu sangat dipengaruhi oleh atribut sosial ekonomi. Atribut yang dimaksud adalah:

- Tingkat pendapatan: biasanya terdapat tiga tingkat pendapatan di Indonesia, yaitu tinggi, menengah dan rendah.

- Tingkat pemilikan kendaraan: biasanya terdapat empat tingkat yaitu $0,1,2$ atau lebih dari dua (2+) kendaraan per rumah tangga.

- Ukuran dan struktur rumah tangga.

\section{Trayek angkutan umum}

a. Jaringan Trayek

Berdasarkan Anonim (2002), jaringan trayek adalah kumpulan trayek yang menjadi satu kesatuan pelayanan angkutan orang. Faktor 
yang digunakan sebagai pertimbangan dalam menerapkan jaringan trayek adalah sebagai berikut:

1. Pola Tata Guna Lahan

2. Pola Pergerakan Penumpang Angkutan Umum

3. Kepadatan Penduduk

4. Daerah Pelayanan

5. Karakteristik Jaringan Jalan

a. Macam-Macam Jaringan Trayek

Menurut Anonim tahun 1993, jaringan trayek terbagi atas:

1. Trayek antar kota dalam propinsi yaitu trayek yang melalui antar Daerah Tingkat II dalam satu wilayah Propinsi Daerah Tingkat I. Trayek antar kota dalam propinsi diselenggarakan dengan memenuhi ciri-ciri pelayanan sebagai berikut:

a. Mempunyai jadwal yang tetap

b. Pelayanan cepat dan atau lambat

c. Dilayani oleh mobil bus umum

d. Prasarana jalan yang dilalui memenuhi ketentuan kelas jalan

2. Trayek kota yaitu trayek yang seluruhnya berada dalam satu wilayah kotamadya. Daerah Tingkat II atau trayek dalam daerah khusus ibukota. Trayek kota terdiri dari:

a. Trayek utama

b. Trayek cabang

c. Trayek ranting

d. Trayek langsung kabupaten Daerah Tingkat II.

4. Trayek lintas batas Negara yaitu trayek yang melewati atau melewati batas Negara.

\section{Tarif Angkutan Umum}

Anonim (2002), tarif adalah besarnya biaya yang dikenakan pada setiap penumpang kendaraan angkutan umum yang dinyatakan dalam rupiah. Penetapan tarif dimasukkan untuk mendorong terciptanya penggunaan prasarana dan sarana pengangkutan secara optimum dengan mempertimbangkan lintasan yang bersangkutan. Perhitungan tarif angkutan umum merupakan hasil perkalian antara tarif pokok dan jarak tempuh rata-rata satu perjalanan (tarif Break Event Point) di tambah $10 \%$ untuk keuntungan jasa perusahaan. Secara matematis dapat di rumuskan seperti persamaan (1), (2) dan (3) sebagai berikut:

Tarif $=($ Tarif pokok $x$ jarak rata-rata $)$

$$
+10 \% \text { tarif } B E P
$$

Tarif BEP $=($ Tarif pokok $\times$ jarak rata-rata $)$ (2)

Tarif pokok $=\frac{\text { total biaya pokok }}{\text { faktor pengisian } x \text { kapasitas kendaraan }}$

Menurut Warpani (2002), faktor muat penumpang (loading factor) adalah nisbah antara jumlah penumpang yang diangkut dengan daya tampung atau kapasitas kendaraan selama satu lintasan. Faktor muat dapat dihitung dengan persamaan (4) sebagai berikut:

$$
F=\frac{P}{K} \times 100
$$
seluruhnya berada dalam satu wilayah 
Keterangan:

$\mathrm{F} \quad=$ Faktor muat (loading factor).

$\mathrm{P} \quad=$ Banyaknya penumpang yang diangkut sepanjang satu lintasan sekali jalan.

$\mathrm{K}=$ Daya tampung kendaraan yang diijinkan.

\section{Sistem pembentukan tarif angkutan umum}

Tarif bagi penyedia jasa angkutan adalah harga dari jasa yang diberikan. Sedangkan bagi pengguna jasa, besarnya tarif merupakan biaya yang harus dibayarkan untuk jasa yang telah dipakainya. Penentuan tarif ini harus berdasarkan sistem pembentukannya yang diatur oleh pemerintah.

\section{Jenis tarif angkutan umum}

Menurut Anonim (2002), tarif angkutan adalah suatu daftar yang memuat harga-harga untuk para pemakai angkutan yang disusun secara teratur. Pembebanan dalam harga dihitung menurut kemampuan transportasi (What Traffic Will Bear). Adapun jenis tarif yang berlaku dapat dikelompokkan sebagai berikut:

\section{Tarif Seragam (Flat Fare)}

Pada sistem ini, tarif dikenakan tanpa memperhatikan jarak yang ditempuh, baik perjalanan jarak pendek maupun jauh dikenakan tarif yang sama. Pengertian tarif seragam ini dapat dilihat pada Gambar 1.

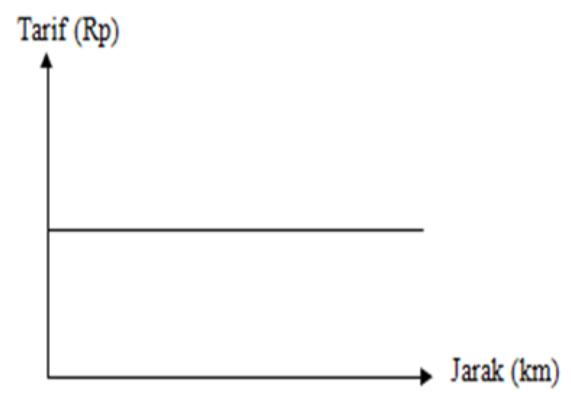

Gambar 1 Tarif Seragam

Sumber: Onza, T (2015)

1. Tarif Berdasarkan Jarak (Distance-Based Fare)

Sistem tarif ini ditentukan berdasarkan jarak yang ditempuh, yaitu besarnya tarif yang ditetapkan adalah perkalian besar tarif perkilometer dengan panjang perjalanan, di mana jarak minimum dan tarif minimum ditetapkan nilai terlebih dahulu. Pengertian tarif berdasarkan jarak ini diperlihatkan pada Gambar 2.

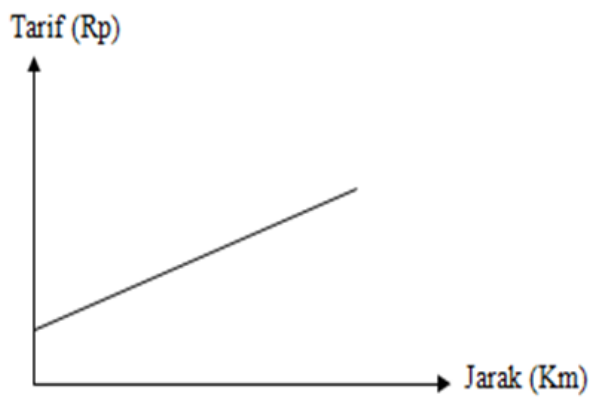

Gambar 2 Tarif Berdasarkan Jarak

Sumber: Onza, T (2015)

\section{Tarif Bertahap}

Sistem tarif ini didasarkan pada jarak yang ditempuh oleh penumpang yang di bagi persatuan tahapan. Pengertian tarif bertahap ini di perlihatkan pada Gambar 3. 


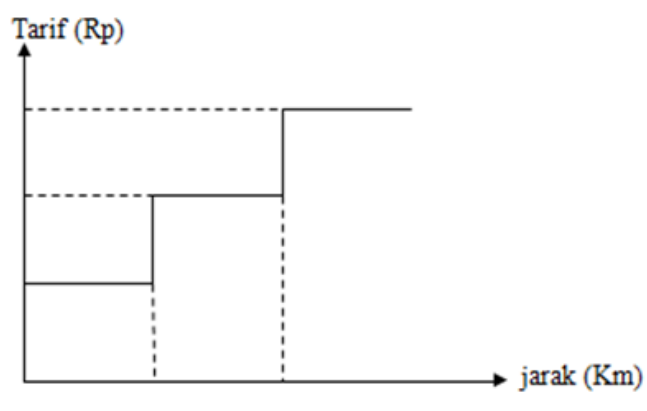

Gambar 3 Tarif Bertahap

Sumber: Onza, T (2015)

\section{Tarif Zona}

Sistem tarif ini adalah penyederhanaan dari tarif bertahap dimana daerah pelayanan perangkutan tersebut dibagi kedalam zonazona. Pengertian tarif zona ini di perlihatkan pada Gambar 4.

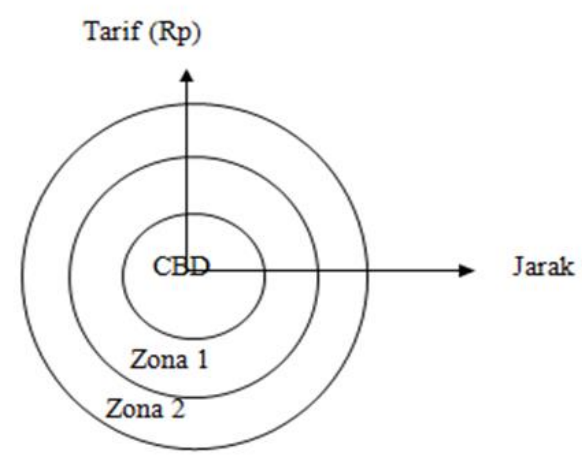

Gambar 4 Tarif Berdasarkan Zona

Sumber: Onza, T(2015)

\section{Biaya Operasional Kendaraan}

Biaya operasional kendaraan adalah biaya yang secara ekonomis terjadi karena di operasikannya satu kendaraan pada kondisi normal untuk suatu tujuan tertentu. Menurut Anonim (2002), biaya operasi kendaraan (angkutan) dapat dibagi menjadi dua, Biaya Langsung dan Biaya Tak Langsung.

\section{Biaya langsung}

Biaya langsung adalah biaya yang langsung dapat dibebankan pada biaya operasi kendaraan atau biaya pokok, dan dapat dibagi lagi menjadi:

1) Biaya Tetap (fixed cost)

Biaya tetap adalah biaya yang tidak berubah-ubah atau tidak terpengaruh karena pengoperasian kendaraan. Biaya tetap terdiri dari empat komponen yaitu:
a) Penyusutan kendaraan
b) Bunga modal
c) Pajak kendaraan
d) Pendapatan awak kendaraan

2) Biaya Berubah (variable cost)

Berbeda dengan biaya tetap, biaya berubah (variable cost) besarnya bergantung pada pengoperasian kendaraan. Biaya berubah ini terdiri dari:

a) Bahan Bakar Minyak (BBM)

b) Ban kendaraan

c) Servis kecil

d) Servis besar

e) Overhaul

f) Penambahan Oli Mesin

g) Cuci Kendaraan

h) Retribusi Terminal

i) Pemeriksaan Kendaraan

j) Asuransi

\section{Biaya tak langsung}

Menurut Warpani (2002), biaya tak langsung adalah biaya yang tak dapat langsung dikenakan terhadap operasi perangkutan, tetapi menjadi bagian dari biaya pokok dan unit biaya. 
Biaya langsung terbagi atas dua, yaitu:

1) Biaya pokok

Biaya pokok adalah biaya dasar yang dikenakan antara lain pada lokasi, peralatan dan prasarana.

\section{2) Biaya umum (overhead cost)}

Biaya umum adalah biaya tak langsung yang timbul sebagai akibat dari kegiatan angkutan.

\section{Biaya pokok produksi angkutan umum}

Menurut Anonim (2002), biaya pokok angkutan umum adalah besarnya biaya yang harus dikeluarkan oleh operator untuk dapat menghasilkan satuan produksi pelayanan angkutan umum atau secara otomatis dapat dikatakan bahwa biaya pokok produksi angkutan umum adalah total biaya operasi kendaraan per tahun dibagi dengan total produksi pelayanan per tahun. Biaya pokok produksi angkutan umum dapat dihitung dengan persamaan (5) berikut:

$$
B P P=\frac{B O K}{T P P}
$$

Di mana:

BPP $=$ Biaya Pokok Produksi (Rp./pnp)

$\mathrm{BOK}=$ Total Biaya Operasi Kendaraan $(\mathrm{Rp})$

TPP $=$ Total Produksi Pelayanan (pnp-km)

Besar Biaya Operasi Kendaraan (BOK)

dan Produksi Pelayanan (TPP) dapat dihitung dengan menggunakan persamaan (6) dan (7) berikut ini:

BOK=Biaya langsung + Biaya tak langsung

$B O K=\frac{\text { Biaya langsung }+ \text { Biaya tak langsung }}{\text { Tarif pokok } x \text { jarak rata-rata }}$

\section{ATP (Ability To Pay)}

Menurut Yuniarty (2009), Ability To Pay (ATP) adalah kemampuan seseorang untuk membayar jasa angkutan yang diterimanya berdasarkan penghasilan yang dianggap ideal. Pendekatan yang digunakan dalam analisa ATP didasarkan pada alokasi biaya untuk transportasi dan intensitas perjalanan pengguna. Besar ATP adalah rasio anggaran untuk transportasi dengan intensitas perjalanan.

\section{METODE PENELITIAN}

Pada penelitian ini dilakukan tahapan sesuai dengan maksud dan tujuan dari penelitian, serta batasan dan ruang lingkup penelitian meliputi: studi literatur, pengumpulan data primer dan skunder serta evaluasi data. Analisa data yang digunakan adalah berdasarkan tinjauan dari jenis biaya yang dikeluarkan angkutan umum perkotaan pada masing-masing trayek pelayanan dan kemudian dianalisis besarnya biaya operasional kendaraan berdasarkan teoritis dan hasil survei dengan bantuan program microsoft excel.

\section{Pengambilan data sekunder}

Sebelum dilakukan survei ke lapangan terlebih dahulu dilaksanakan pengumpulan data sekunder yaitu:

1. Data jenis trayek angkutan antar kota serta rute yang dilewati, yang dapat diperoleh dari Dinas Perhubungan Provinsi Aceh.

2. Data tarif dari Organda. 


\section{Pengambilan data primer}

Data primer adalah data yang diperoleh dari pengamatan yang dilakukan di lokasi studi. Pelaksanaan survei untuk mendapatkan data primer dilakukan dengan cara:

a. Survei on Board (peneliti berada dalam kendaraan) yaitu survei terhadap kendaraan (angkutan) secara fisik, dan pengamatan terhadap kinerja pelayanan angkutan umum meliputi rute, panjang rute, jumlah angkutan, jumlah penumpang, dan faktor muat (load factor) secara langsung dengan pengamat berada dalam kendaraan. Survei dilakukan dalam waktu 2 minggu. Minggu pertama untuk tujuan dari Blang Pidie ke Banda Aceh pada hari: Senin, Selasa, Sabtu, Minggu sedangkan, Minggu kedua tujuan Banda Aceh ke Blang Pidie pada hari: Senin, Selasa, Sabtu, Minggu.

b. Survei Investigasi, yaitu wawancara langsung terhadap sopir untuk memperoleh data Biaya Operasi Kendaraan (BOK).

\section{Periode Pengamatan}

Berdasarkan berbagai pengamatan di lapangan untuk mendapatkan data aspek operasional angkutan umum yang telah dilakukan maupun berdasarkan dari berbagai acuan, maka dalam melakukan survei ini dilakukan dengan mengikuti kendaraan dari rute asal ke rute akhir.

\section{Pengambilan Data Jumlah Penumpang}

Pengambilan data jumlah penumpang atau banyaknya penumpang yang naik/turun pada suatu kendaraan dilakukan dengan mencatat jumlah penumpang yang naik/turun dan jumlah penumpang diatas kendaraan sepanjang trayek perjalanan yang beroperasi pada hari survei.

\section{Analisa Data}

1. Faktor Muatan Penumpang (Load Factor)

Faktor muatan penumpang adalah sebagai perbandingan antara banyaknya penumpang per jarak dengan kapasitas tempat duduk angkutan umum yang tersedia. Faktor muatan penumpang untuk keberangkatan dari terminal Blang Pidie, setiap hari survei diperoleh dengan cara membagikan jumlah penumpang setiap sampel dengan kapasitas tempat duduk yang tersedia, kemudian dihitung faktor muatan penumpang rata-rata untuk setiap hari survei, dengan menggunakan Persamaan (4).

\section{Analisa Biaya Operasi Kendaraan (BOK)}

Untuk mengetahui besaran biaya operasi kendaraan diperlukan analisa terhadap hubungan kerja antara pengusaha (operator) dan sopir angkutan umum antar kota terlebih dahulu.

\section{Analisa Biaya Pokok Pelayanan}

Biaya Pokok Pelayanan angkutan umum adalah biaya yang harus dikeluarkan oleh pihak operator untuk dapat menghasilkan 
satuan produksi pelayanan angkutan umum. Berdasarkan defenisi ini maka besaran biaya pokok pelayanan angkutan akan sangat dipengaruhi oleh besaran biaya pokok operasional per satuan waktu dan besaran produksi pelayanan angkutan per satuan waktu, dengan menggunakan Persamaan (5).

\section{Analisa Tarif Angkutan Umum}

Perhitungan tarif angkutan umum merupakan hasil perkalian antara tarif pokok dan jarak (kilometer) rata-rata satu perjalanan (tarif Break Event Point) dan di tambah $10 \%$ untuk keuntungan jasa perusahaan, dengan menggunakan Persamaan (1).

\section{Analisa ATP (Ability To Pay)}

Analisa ATP dilakukan dengan menggunakan analisa berdasarkan alokasi biaya transfortasi dan intensitas perjalanan pengguna jasa anggkutan umum,serta kesanggupan masyarakat dalam mengeluarkan imbalan atas jasa yang diperolehnya sesuai dengan kondisi ekonomi dan sosial budaya, dengan menggunakan Persamaan (8).

\section{Evaluasi Tarif}

Evaluasi tarif pada dasarnya dilakukan dengan menggunakan tiga informasi yang telah di peroleh sebelumnya, yaitu berdasarkan Biaya Operasi Kendaraan (BOK), Kesesuaian tarif yang berlaku saat ini dengan hasil analisa berdasarkan Biaya Operasi Kendaraan (BOK) dan kemampuan penumpang membayar tarif angkutan umum yang berlaku. Ketiga informasi dasar tersebut digabungkan, mengingat bahwa prinsip dasar dari suatu tarif adalah suatu besaran atau struktur yang mampu mengakomodasi dua kepentingan, kepentingan pemilik angkutan umum dan kepentingan masyarakat sebagai pengguna jasa angkutan umum. Dimana kepentingan pemilik angkutan umum dapat direpresentasikan dengan besaran biaya pokok kendaraan dan biaya di lapangan.

\section{HASIL PEMBAHASAN}

Hasil dan pembahasan pada penelitian ini mengacu pada metodologi dan sesuai dengan teori-teori serta persamaanpersamaan sebagaimana yang telah dibahas pada tinjauan kepustakaan terhadap analisis tarif angkutan umum berdasarkan biaya operasi kendaraan dan kemampuan seseorang untuk membayar jasa angkutan yang diterimanya berdasarkan penghasilan yang dianggap ideal pada trayek Blang Pidie-Banda Aceh.

Pada penelitian tarif angkutan umum trayek Blang Pidie-Banda Aceh sistim tarif yang berlaku sistim tarif berdasarkan tahapan, dapat dilihat pada Gambar 5 grafik analisa tarif berdasarkan tahapan atau lokasi dibawah ini: 


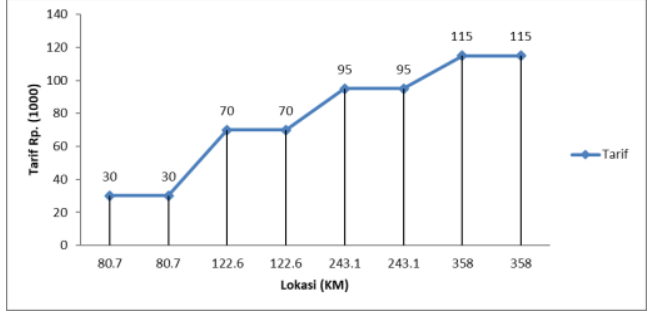

Gambar 5 Grafik Analisa Tarif Berdasarkan Tahapan atau Lokasi

\section{Faktor Muatan Penumpang (Load Factor)}

Faktor muatan penumpang adalah perbandingan antara banyaknya penumpang per jarak dengan kapasitas tempat duduk angkutan umum 8 orang yang tersedia. Faktor muatan penumpang untuk keberangkatan dari terminal Blang Pidie setiap hari survei diperoleh dengan cara membagikan jumlah penumpang setiap sampel dengan kapasitas tempat duduk yang tersedia.

\section{Besaran Biaya Operasi Kendaraan}

Dari analisa dan perhitungan di atas dapat diketahui besarnya biaya operasi kendaraan:

$$
\begin{aligned}
B O K= & \text { Biaya Langsung }+ \text { Biaya Tak } \\
& \text { Langsung } \\
= & R p 2.196+\text { Rp 8.000,- } \\
= & R p 10.196,-/ \text { Kend } .
\end{aligned}
$$

\section{Besaran Biaya Pokok Pelayanan}

a. Total Produksi Pelayanan (TPP)

$$
\begin{aligned}
& T P P=\frac{B O K}{\text { Tarif Pokok } x \text { Jarak Rata-Rata }} \\
& =\frac{R p \text { 10.196 Kend. }-k m}{(R p 318,64 \times 358)} \\
& =R p 0.089 / P n p-k m
\end{aligned}
$$

b. Biaya Pokok Produksi (BPP)

$$
\begin{aligned}
B P P=\frac{B O K}{T P P} & =\frac{R p 10.196 \text { Kend. }-k m}{R p 0.089 / \text { Pnp }-k m} \\
& =R p 125,480 / \text { Pnp }
\end{aligned}
$$

Dari hasil perhitungan Biaya Operasi Kendaraan (BOK) dan Total Produksi Pelayanan (TPP) diatas dapat dihitung Biaya Pokok Produksi (BPP) rata-rata kendaraan, dapat dilihat pada Tabel 1 Rekapitulasi Biaya Pokok Produksi sebagai berikut:

Tabel 1 Rekapitulasi Biaya Pokok Produksi

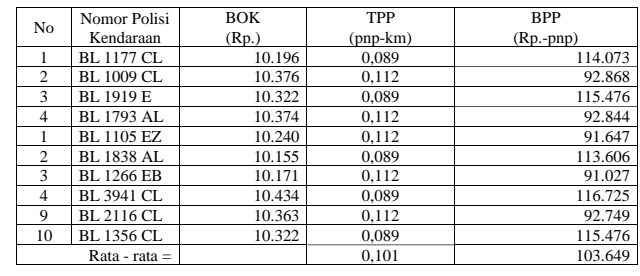

\section{Analisa Tarif Berdasarkan BOK}

Perhitungan tarif angkutan umum merupakan hasil perkalian antara tarif pokok dan jarak (kilometer) rata-rata satu perjalanan (tarif Break Event Point) dan di tambah $10 \%$ untuk keuntungan jasa perusahaan, berdasarkan penyebaran kuesioner dan wawancara dengan pihak angkutan maupun pihak pengguna jasa angkutan umum trayek Blang Pidie - Banda Aceh dalam sekali lintas trayek terdapat penumpang naik dan turun sesuai dengan tujuan pengguna jasa angkutan, dari total jarak Blang Pidie-Banda Aceh adalah 358 $\mathrm{Km}$.

Perhitungan analisa tarif dapat ditunjukkan dalam bentuk grafik seperti Gambar 6 grafik analisa tarif trayek Blang Pidie-Banda Aceh. 


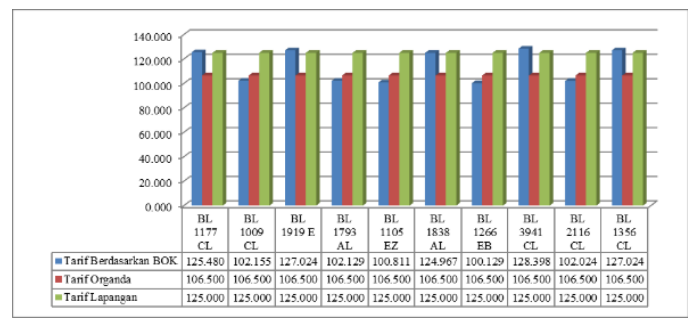

Gambar 6 Grafik analisa tarif trayek Blang Pidie-Banda Aceh

\section{ATP (Ability To Pay)}

Ability To Pay (ATP) adalah kemampuan seseorang untuk membayar jasa angkutan yang diterimanya berdasarkan penghasilan yang dianggap ideal. Berdasarkan hasil wawancara dan penyebaran kuesioner dengan pihak pengguna jasa angkutan umum trayek Blang Pidie-Banda Aceh atau sebaliknya trayek Banda-Blang Pidie diperoleh data pendapatan rata-rata pihak pengguna jasa angkutan umum Rp. 2.500.000 dan standar ideal biaya untuk transportasi $20 \%$ dengan hari optimal kerja 24 hari. Maka diperoleh biaya ATP rata-rata dari tiap trayek sebagai berikut

$$
\begin{aligned}
A T P & =\frac{\text { Pendapatan rata-rata perbulan } x \text { Standar ideal biaya transportasi }}{\text { Hari optimal Kerja }} \\
& =\frac{R p 2.500 .000 / \text { bulan } \times 20 \%}{24}
\end{aligned}
$$

$=R p 208.333$

\section{KESIMPULAN DAN SARAN}

\section{Kesimpulan}

Berdasarkan penelitian yang dilakukan pada angkutan antar kota di Kota Blang Pidie, maka dapat disimpulkan beberapa hal sebagai berikut:
1. tarif yang ditetapkan pemerintah lebih kecil dari tarif yang berlaku di lapangan. Namun ternyata, tarif berdasarkan perhitungan biaya operasi kendaraan lebih besar di bandingkan dengan tarif yang ditetapkan pemerintah dan lebih kecil dari tarif yang berlaku di lapangan.

2. Secara umum kinerja pelayanan angkutan umum antar kota sangat lancar, dan sistem koordinasi antara operator (pengusaha) angkutan terhadap sopir dan kendaraan sudah cukup baik karena angkutan antar kota sudah beroperasi secara efisien.

3. Faktor muatan penumpang rata-rata angkutan antar kota Trayek Blang Pidie-Banda adalah sebesar 56,25\%.

4. Tarif berdasarkan Biaya Operasional Kendaraan (BOK) lebih kecil bila dibandingkan dengan tarif yang berlaku di lapangan dan tarif yang berlaku di lapangan juga lebih tinggi dari tarif yang ditetapkan Pemerintah kota setempat. Tarif rata-rata yang ditetapkan pemerintah adalah Rp.106.500/Pnp, tarif rata-rata teoritis hasil perhitungan BOK trayek Blang Pidie-Banda Aceh adalah Rp.114.014,/Pnp, dan tarif rata-rata yang berlaku di lapangan adalah Rp. 125.000-Rp. $150.000 /$ Pnp.

5. Biaya Pokok Produksi Pelayanan ratarata kendaraan diperoleh pada trayek Blang Pidie-Banda Aceh sebesar Rp. 
103,649,-/Pnp-km.

6. kemampuan membayar pengguna jasa angkutan umum ATP (Ability To Pay) sebesar Rp. 208.333,-

\section{Saran}

1. perlu adanya peningkatan peran pemerintah setempat dalam mengevaluasi tarif angkutan kembali serta mengembangkan alternatifalternatif kebijakan lain oleh pemerintah dalam menangani permasalahan ini.

2. Hasil penelitian ini tentunya berlaku untuk situasi, kondisi dan waktu yang sesuai dengan saat dilakukan penelitian ini, seiring dengan berjalannya waktu tentunya perlu dilakukan penelitian yang sesuai dengan keadaan sebenarnya karena akan selalu terjadi perubahanperubahan sesuai dengan dinamika dalam angkutan antar kota tersebut.

\section{DAFTAR PUSTAKA}

Anonim. (1993). Macam Macam Jaringan Trayek, PP No. 41. Jakarta

Anonim. (2002). Pedoman Teknis Penyelenggaraan Angkutan Penumpang Umum Di Wilayah Perkotaan Dalam Trayek Tetap Dan

Teratur (SK.687/AJ.206/DRJD/2002), Keputusan Direktur Jenderal Perhubungan Darat, Jakarta

Onza Tiranda. (2015). Analisis Tarif Angkutan Antar Kota Berdasarkan Biaya Operasi Kendaraan (BOK)
(Studi kasus Dari Kota Langsa Ke

Kota Banda Aceh). Universitas Sumatera Utara

Ridwan. TM.. (2013). Studi Penentuan Tarif Penumpang Angkutan Bus Sedang. Teras Jurnal, Vol 3, No 2, September 2013 Jurusan Teknik Sipil, Fakultas Teknik, Universitas Malikussaleh.

Rizky Fahlevi. M. (2006). Unsur-Unsur Pokok Transportasi Umum. Universitas Sumatera Utara.

Slovin. Sevilla, Consuelo G. et al,. (2007). Research Methods. Quezon City: Rex Printing Company.

Tamin, Z, Ofyar. (2000). Perencanaan dan Pemodelan Transportasi. Bandung: ITB.

Warpani. (2002). Penggelolaan Jalan dan Angkutan Jalan. Bandung: ITB,

Yuniarti, Taty. (2009). Analisis Tarif Angkutan Umum Berdasarkan Biaya Operasional Kendaraan, Ability To Pay Dan Willingness To Pay, Skripsi Fakultas Teknik Universitas Sebelas Maret, Surakarta.

- How to cite this paper :

Zardi, M., Meliyana, M., \& Mahdiainda, D. (2018). Analisis Tarif Angkutan Umum Berdasarkan Biaya Operasi Kendaraan. Jurnal Teknik Sipil Unaya, 4(2), 5162. 